\title{
MODEL RIAP TEGAKAN HUTAN ALAM PRODUKSI DI PULAU BURU - MALUKU
}

\author{
Increment Model of Natural Forest Production at Buru Island - Maluku \\ Luthfy Abdullah ${ }^{1)}$ dan/and Darwo ${ }^{2)}$ \\ ${ }^{1}$ Pusat Penelitian dan Pengembangan Keteknikan Kehutanan dan Pengolahan Hasil Hutan \\ Jl. Gunung Batu No. 5 Bogor 16118. Telp. 0251-8631238, Fax. 0251-7520005 \\ e-mail: Lutfyabdulah@yahoo.co.id; darwo_iph@yahoo.co.id
}

Naskah masuk : 17 Februari 2014; Naskah diterima : 19 Maret 2015

\begin{abstract}
Decisions on natural forest production management are still based on sustainable yield principles because forest management is still sustainability of standing stock rather than sustainability of ecology and social aspects. Diameter increment is an important factor for measuring possible income of management unit and understanding field standing stock. This study aims is to construct a model based on diameter class and tree species group. The study uses a statistical modeling of permanent sampling plots (PSP). The results show that current anual increament (CAI) is $1.3 \mathrm{~cm} \mathrm{yr}^{-1}$ at 10-20 diameter class and $0.78 \mathrm{~cm} \mathrm{yr}^{-1}$ for diameter class larger than $40 \mathrm{~cm}$. CAI of commercial groups are higher than it of non-commercial groups. Meanwhile, CAI for Dipterocarpaceae and Myrtaceae families are higher than those for Burseraceae, Fagaceae, Guttiferae and Lauraceae families. The model for all tree species is $C A I=2.19 e^{-0.028 D}$, and for each tree species group is different .
\end{abstract}

Keywords: Diameter class, species group, increament model

\begin{abstract}
ABSTRAK
Kajian riap pertumbuhan di hutan alam telah dilakukan dan masih berlangsung untuk memperoleh suatu model dugaan yang mampu menjelaskan pertumbuhan yang sebenarnya. Penggunaan metode penduga riap pertumbuhan masih merupakan alat utama pengambilan keputusan dalam manajemen hutan alam produksi. Keputusan manajemen hutan alam produksi dewasa ini masih berada pada prinsip kelestarian hasil. Hal ini dikarenakan unit manajemen masih memandang kelestarian hutan dari keberadaan pohon dan keberlangsungan pemanenan setiap tahunnya. Kajian riap berdasarkan jenis dominan perlu dilakukan sebagai alat pengukur pendapatan perusahaan dan sekaligus untuk membantu pemahaman potensi tegakan tinggal. Penelitian ini bertujuan untuk menduga riap pertumbuhan diameter berdasarkan kelas diameter dan kelompok jenis. Metode yang digunakan dalam penelitian ini adalah membangun model statistik dari data PUP. Hasil penelitian menunjukkan bahwa CAI 1,3 cm/tahun pada kelas diameter 10-20 dan 0,78 cm/tahun pada kelas diameter terbesar $40 \mathrm{~cm}$ ke atas. CAI kelompok jenis komersil lebih besar dibandingkan kelompok jenis non-komersil. Sementara itu, CAI famili Dipterocarpaceae dan Myrtaceae lebih besar dibandingkan famili Burceraceae, Fagaceae, Guttiferae dan Lauraceae. Model penduga CAI untuk semua jenis di Pulau Buru adalah CAI $=2,19 \mathrm{e}^{-}$0,028D. Untuk masing-masing kelompok jenis pohon memiliki bentuk persamaan yang berbeda. Namun demikian, model ini perlu dikaji lanjut di lapangan untuk menguji keterandalannya sebagai alat penduga pengaturan hasil.
\end{abstract}

Kata kunci: Kelas diameter, kelompok jenis, model riap 


\section{PENDAHULUAN}

Pengaturan hasil hutan dengan menggunakan konsep etat luas dan etat volume dianggap tidak sesuai lagi dengan kondisi hutan saat ini. Sistem pengaturan hasil seperti ini cenderung meninggalkan jumlah tegakan tersisa semakin sedikit dan tidak menjamin pengusahaan hutan produksi pada siklus tebang berikutnya. Hal ini disebabkan pengaturan hasil dengan dasar etat volume atau etat luas bersifat penyederhanaan, semua areal yang ditebang akan tumbuh dengan laju yang sama dan tidak ada faktor eksternal yang mempengaruhi (Parthama, 2002). Padahal seharusnya pengaturan hasil hutan alam produksi mempertimbangkan riap tegakan.

Penentuan AAC (Annual Allowable Cut) atau jatah tebang tahunan perlu mempertimbangkan riap. Penentuan riap selama ini cenderung bersifat umum, baik dari segi lokasi maupun kelompok jenis. Sementara riap (terutama riap diameter) setiap kelompok jenis berbeda-beda menurut kelas diameter dan kelompok jenis. Sebagai contoh, Septiana (2000) menyebutkan bahwa riap diameter rata-rata tahunan di Kalimantan Timur untuk jenis meranti pada kelas diameter $20 \mathrm{~cm}$ up berkisar antara 0,76-1,15 cm/tahun, sementara untuk jenis komersil non-meranti mencapai 0,67-0,77 cm/tahun dan untuk jenis non-komersil mencapai 0,29-0,61 cm/tahun. Agustini (2006) me-nyebutkan bahwa riap di Kalimantan Barat untuk jenis meranti mencapai $0,56 \mathrm{~cm} /$ tahun, sementara untuk jenis non-meranti mencapai 0,37 $\mathrm{cm} /$ tahun. Riap untuk jenis meranti di seluruh Indonesia mencapai 0,6 cm/tahun (Yudistira, 2004).

Berdasarkan penelitian-penelitian di atas, pendugaan riap masih berdasarkan pengelompokkan jenis dengan sifat komersil. Untuk itu, penelitian ini mencoba untuk menggambarkan pertumbuhan riap diameter berdasarkan kelompok jenis pada kelas diameter. Hal ini disebabkan oleh laju permintaan kayu yang tinggi mengakibatkan semua kayu memiliki nilai ekonomi, meskipun berbeda kualitas kaya serta kelimpahannya dalam struktur tegakan akan tripis. Pertimbangan pengelompokan tiap diameter Gourlet-Fleury et al., (2005). Menyatakan bahwa 3 strategi utama dalam klasifikasi jenis yakni berdasarkan tujuan ekologi (ecologycal subjective group), kelompok data ekologi (ecologycal data-driven groups) dan kelompok proses dinamika (dynamic process group). Untuk itu, penelitian ini bertujuan untuk mempelajari riap pertumbuhan diameter berdasarkan kelas diameter, riap diameter berdasarkan kelompok jenis dan membangun model penduga riap rata-rata tahun berjalan (CAI, current annual increament) berdasarkan kelompok jenis. Rumusan masalah penelitian ini sama dengan penelitian Saaludin, Yahya, Harun, \& Wan Ahmad (2014). Bedanya penelitian ini hanya menyusun model diameter atas 2 kelompok jenis besar yakni dipterokarpa dan non-dipterokarpa.

\section{METODOLOGI}

\section{A. Metode Pengumpulan Data}

Data yang digunakan berasal dari data pengukuran Petak Ukur Permanen (PUP) yang dilakukan oleh PT. Gema Hutani Lestari di pulau Buru, Maluku. PUP dibuat pada blok RKT (Rencana Kerja Tahunan) 2003 yang diukur mulai tahun 2007, 2008, 2009, 2010 dan 2011. Terdapat 6 petak ukur yang letaknya berdekatan dengan klasifikasi 3 petak ukur dengan perlakuan pemeliharaan dan 3 petak ukur tanpa perlakuan pemeliharaan. Namun dalam penelitian ini, kami tidak membedakan data PUP berdasarkan tindakan pemeliharaan tersebut. Luas setiap PUP adalah 1 hektar dengan jumlah dan komposisi jenis bervariasi. PUP terletak di dekat sungai waemutu.

Data PUP terdiri atas data jenis dalam nama lokal dan nama ilmiah, famili dan kelompok jenis dan tinggi dan diameter yang diukur secara berulang selama 5 tahun. Namun demikian, masih terdapat sejumlah jenis pohon yang belum diketahui nama ilmiah dan juga sejumlah pohon yang masih menggunakan nama lokal. Adapun sebaran data dapat dilihat pada Tabel 1.

Berdasarkan Tabel 1 dapat dilihat bahwa jenis Dipterocarpaceae tersebar merata di seluruh PUP. Sementara secara keseluruhan jumlah individu pada kelompok jenis komersil lebih besar diban- 
Tabel (Table) 1. Sebaran data menurut PUP (Data distribution by PSP)

\begin{tabular}{|c|c|c|c|c|c|c|c|c|}
\hline \multirow{2}{*}{$\begin{array}{l}\text { Golongan } \\
\text { (Group) }\end{array}$} & \multirow{2}{*}{ Famili (Family) } & \multicolumn{6}{|c|}{ PUP (PSP) } & \multirow{2}{*}{$\begin{array}{l}\text { Jumlah } \\
\text { (Sum) }\end{array}$} \\
\hline & & 1 & 2 & 3 & 4 & 5 & 6 & \\
\hline \multirow[t]{10}{*}{ Komersil } & Tidak diketahui & 1 & & & & & 2 & 3 \\
\hline & Arauc. & & 12 & 2 & 8 & 4 & 10 & 36 \\
\hline & Burs. & 30 & 3 & 5 & 5 & 7 & 13 & 63 \\
\hline & Dipt. & 54 & 49 & 53 & 67 & 63 & 73 & 359 \\
\hline & Fag. & 33 & 41 & 7 & 82 & 88 & 5 & 256 \\
\hline & Gutt. & 15 & 13 & 42 & & 1 & & 71 \\
\hline & Laur. & 11 & 8 & 5 & 13 & 14 & 42 & 93 \\
\hline & Myrt. & 65 & 38 & 76 & 32 & 36 & 72 & 319 \\
\hline & Stec. & 1 & & & & & & 1 \\
\hline & Ulm. & 1 & & & 2 & & 2 & 5 \\
\hline Jumlah & & 211 & 164 & 190 & 209 & 213 & 219 & 1206 \\
\hline \multirow[t]{6}{*}{ Non-komersil } & Tidak diketahui & 121 & 51 & 122 & 109 & 132 & 280 & 815 \\
\hline & Apec & & & 3 & & & & 3 \\
\hline & Burs. & & & & & & 1 & 1 \\
\hline & Fag. & 1 & & & 1 & & & 2 \\
\hline & Gutt. & 17 & 8 & 40 & 6 & 48 & 27 & 146 \\
\hline & Pod. & & 4 & 1 & 6 & & & 11 \\
\hline Jumlah & & 139 & 63 & 166 & 122 & 180 & 308 & 978 \\
\hline TOTAL & & 350 & 227 & 356 & 331 & 393 & 527 & 2184 \\
\hline
\end{tabular}

dingkan kelompok jenis non-komersil.

\section{B. Analisis Data}

Tahapan analisis data merujuk pada analisis data yang disampaikan Seydack (1995). Adapun tahapan analisis data adalah sebagai berikut:

\section{Penentuan Riap diameter rata-rata tahun ber-jalan}

Riap tahun berjalan (CAI, current annual increament) adalah selisih antara diameter pada tahun ke-n $\left(\mathrm{t}_{\mathrm{n}}\right)$ dengan diameter pada tahun sebelumnya $\left(\mathrm{t}_{\mathrm{n}-1}\right)$, sebagaimana dirumuskan oleh (Pretzsch, 2009) sebagai berikut:

$$
C A I=f(t)=f^{\prime} t=\frac{d D}{d t}
$$

\section{Pengelompokkan data berdasarkan kelas diameter}

Kelas diameter ditentukan dengan lebar kelas $10 \mathrm{~cm}$ dan batas diameter terkecil adalah 10-20 $\mathrm{cm}$ dan batas diameter terbesar adalah $70 \mathrm{~cm}$ up.

\section{Penentuan kelompok famili}

Kelompok famili yang dimaksud didasarkan pada famili dominan yang terdapat di kelompok hutan alam bekas tebangan di Pulau Buru, Maluku. Setiap famili terdiri lebih dari 1 jenis.

Berdasarkan Tabel 2 dapat dilihat bahwa jenis
Shorea selanica mendominasi jenis yang dikenal yakni sebanyak 352 individu. Sementara jenis lokal yakni Castanopsis buruan Mig. Menduduki urutan kedua jumlah individu terbanyak. Sedangkan jenis Pterygota farbosi merupakan jenis yang sangat sedikit dari jenis yang ada. Pengelompokan jenis berdiri karakteristik kelompok data ekologi

\section{Membangun model matematika riap pada setiap jenis}

Model dibangun untuk memahami dan juga untuk memproyeksikan pertumbuhan dan hasil (Vanclay, 2003). Lebih lanjut dijelaskan bahwa model dapat dibangun dari petak pengamatan dan petak percobaan. Berbagai teknik telah dibangun untuk menghasilkan model yang dapat menggambarkan kondisi sebenarnya di lapangan dan kemudian digunakan untuk memproyeksikan. Salah satu teknik yang masih berlaku hingga saat ini adalah model empirik atau model statistik. Vanclay (1994) menjelaskan bahwa dalam membangun model terdapat beberapa pertimbangan yakni (1) model apa yang akan digunakan, (2) input apa yang disiapkan, (3) output yang diinginkan, (4) ketersediaan data, dan (5) ketersediaan sumberdaya untuk membangun, menguji dan menggunakan model tersebut. 
Tabel (Table) 2. Klasifikasi jenis ke dalam famili (Species clasification into family group)

\begin{tabular}{cllc}
\hline \multirow{2}{*}{ No. } & \multicolumn{1}{c}{ Nama latin } & \multicolumn{1}{c}{ Famili } & Jumlah individu \\
\cline { 2 - 4 } & \multicolumn{1}{c}{ (Species) } & Lamily) & (Number of individual) \\
\hline 1 & Actinodapne spp. & Araucariaceae & 93 \\
2 & Agathis alba Foxw & Dipterocarpaceae & 37 \\
3 & Anisoptera spp. & Guttiferae & 20 \\
4 & Calophylum soulatri Burmf & Burseraceae & 60 \\
5 & Canarium sylvestre Gaerth & Fagaceae & 65 \\
6 & Castanopsis buruana Mig. & Myrtaceae & 259 \\
7 & Eucaliptosis papuana CT. & Myrtaceae & 165 \\
8 & Eugenia spp. & Guttiferae & 58 \\
9 & Garcinia sp. & Apec. & 160 \\
10 & Lepiniopsis Ternatensis Val & Myrtaceae & 3 \\
11 & Metrosideros petiolata Kds. & Podocarpaceae & 93 \\
12 & Podocarpus amarus BL & Stec. & 11 \\
13 & Pterygota farbosi & Dipterocarpaceae & 1 \\
14 & Shorea selanica & Cannabaceae & 352 \\
15 & Trema orientalis & Tidak diketahui & 5 \\
16 & Tidak Dikenal & & 804 \\
\hline
\end{tabular}

Memperhatikan pertimbangan tersebut, maka dalam membangun model dipertimbangkan menggunakan model linier, model eksponensial, model geometrik dan model kuadratik. Berikut adalah bentuk umum dari masing-masing model:

1. Model Linier $Y=a+b X \ldots$

2. Model Eksponensial $Y=a e(b X) \ldots$

3. Model Geometrik $Y=a X^{b X}$...

4. Model Power atau Kuadratik $Y=a X^{b}$...

Dimana $\mathrm{Y}$ adalah CAI, dan $\mathrm{X}$ adalah nilai tengah kelas diameter. Model terbaik yang dipilih didasarkan pada kriteria koefisien determinasi $\left(\mathrm{R}^{2}\right)$ yang terbesar dan memiliki simpangan baku terkecil.

\section{Penggunaan model}

Model yang terpilih selanjutnya digunakan untuk memproyeksikan ukuran diameter. Pada tahapan ini, prinsip simulasi pertumbuhan hutan alam yang berbasis kelas diameter dikonversikan menjadi prinsip hutan tanaman dengan basis umur. Hal ini dilakukan dengan maksud mempelajari capaian ukuran diameter setelah penebangan. Simulasi ini mengabaikan faktor kompetisi dan keragaman. Selain itu, yang menjadi pertimbangan utama bahwa setiap individu pohon akan tumbuh normal tanpa adanya pengaruh pertumbuhan lainnya. Simulasi model dilakukan pada siklus tebang 25,30 dan 35 tahun dengan batas diameter minimum adalah $20 \mathrm{~cm}$.

Adapun bentuk umum simulasi dirumuskan sebagai berikut:

$$
D_{t+1}=f\left(D_{t}\right)
$$

Keterangan D: DBH (diameter setinggi dada, 1,3 cm).

\section{HASIL DAN PEMBAHASAN}

\section{A. Hasil}

\section{Riap diameter rata-rata tahun berjalan}

Riap diameter rata-rata tahun berjalan menunjukkan kecenderungan yang menurun berdasarkan kelas diameter. Pertumbuhan riap diameter tahun berjalan (CAI) terbesar terdapat pada kelas diameter terkecil yakni 10-20 mencapai $1,43 \mathrm{~cm} /$ tahun dan turun mencapai $0,8 \mathrm{~cm} /$ tahun pada kelas diameter 60-70 dan $70 \mathrm{~cm}$ up (Gambar 1).

CAI diameter secara umum berbeda setiap kelas diameter. Pada kelas diameter 10-20 cm, CAI diameter mencapai $1,43 \mathrm{~cm} /$ tahun, sementara pada kelas diameter $20-30 \mathrm{~cm}$, CAI diameter mencapai $1,21 \mathrm{~cm} /$ tahun. Pada kelas diameter 30 $-40 \mathrm{~cm}$, CAI diameter mencapai $1,12 \mathrm{~cm}$ dan pada ukuran diameter di atas $40 \mathrm{~cm}$, CAI diameter mencapai 0,78-0,99 $\mathrm{cm} /$ tahun. Adapun karakteristik pertumbuhan riap diameter pada 5 seri pengukuran PUP disajikan pada Tabel 3. 


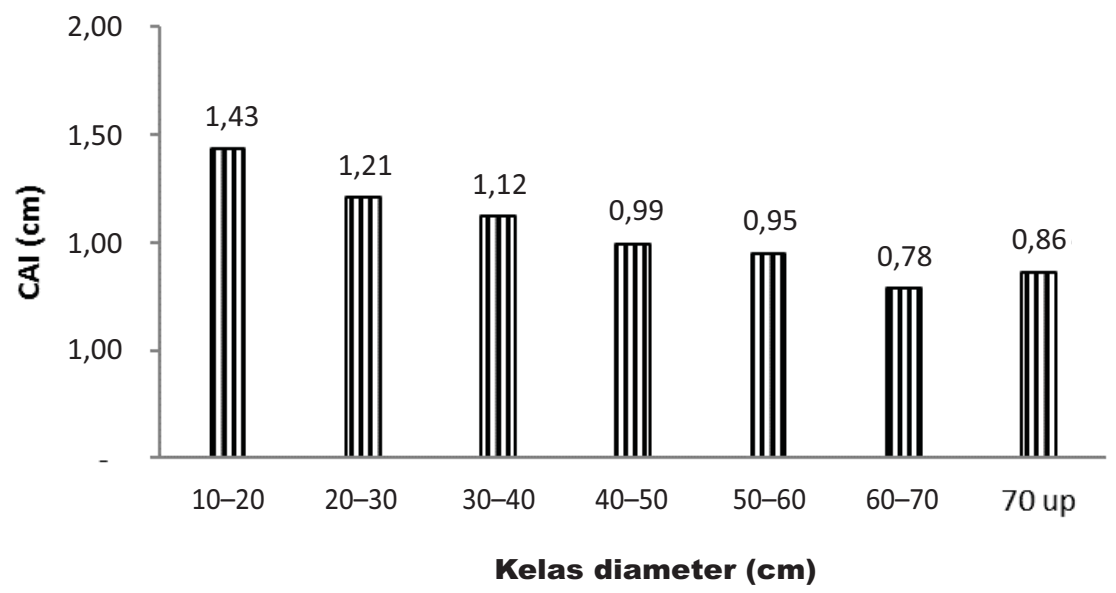

Gambar (Figure) 1. Riap CAI pada setiap kelas diameter (CAI of Each diameter class)

Tabel (Tabel) 3. CAI diameter rata-rata pada setiap pengukuran (Average of CAI at each time)

\begin{tabular}{|c|c|c|c|c|c|}
\hline \multirow{2}{*}{$\begin{array}{l}\text { Kelas Diameter } \\
\text { (Diameter Class) }\end{array}$} & \multicolumn{4}{|c|}{ CAI (cm/tahun) $\left(C A I\right.$, cm.year $\left.^{-1}\right)$} & \multirow{2}{*}{$\begin{array}{l}\text { Rata-rata }(\mathrm{cm} / \text { tahun }) \\
\left.\text { (Average, cm.year }{ }^{-1}\right)\end{array}$} \\
\hline & $2007-2008$ & $2008-2009$ & 2009-2010 & $2010-2011$ & \\
\hline $10-20$ & 0,87 & 1,30 & 1,42 & 2,14 & 1,43 \\
\hline $20-30$ & 1,03 & 1,29 & 1,41 & 1,10 & 1,21 \\
\hline $30-40$ & 0,96 & 1,23 & 1,19 & 1,10 & 1,12 \\
\hline $40-50$ & 0,77 & 0,98 & 0,99 & 1,22 & 0,99 \\
\hline $50-60$ & 0,71 & 0,89 & 1,04 & 1,15 & 0,95 \\
\hline $60-70$ & 0,62 & 0,88 & 0,86 & 0,77 & 0,78 \\
\hline 70 up & 0,69 & 0,95 & 0,77 & 1,03 & 0,86 \\
\hline
\end{tabular}

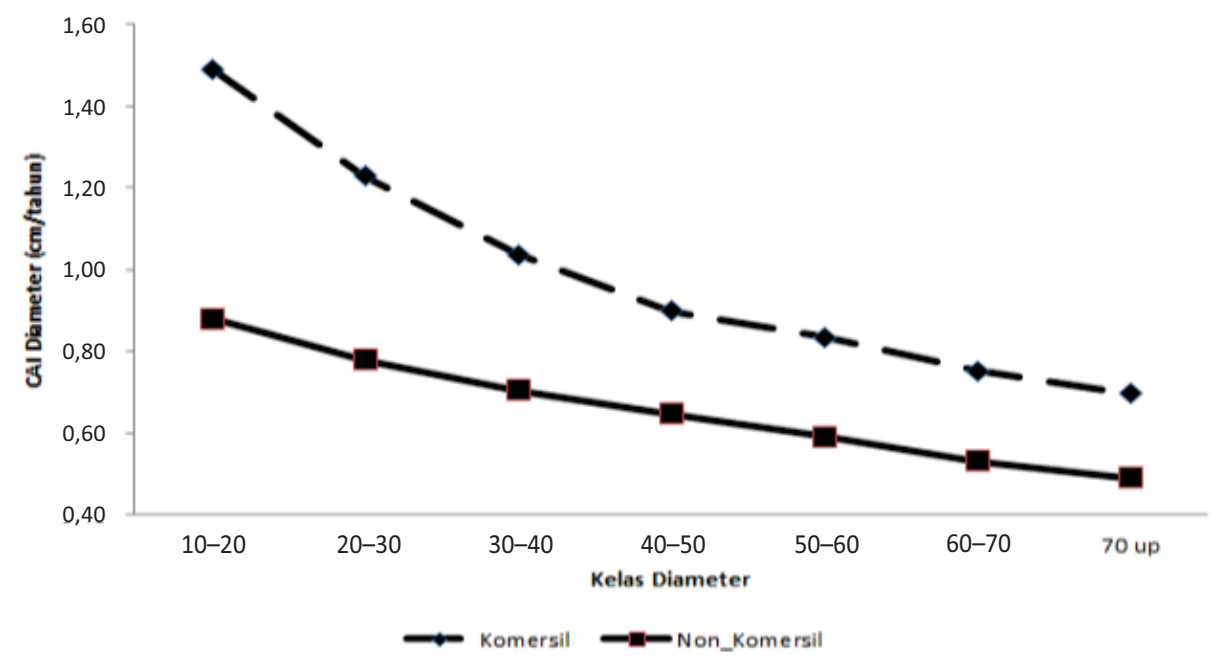

Gambar (Figure) 2. Riap diameter rata-rata berdasarkan golongan jenis komersil (Average ofCAI diameters based on commercial species) 
Tabel (Table) 4. CAI setiap famili pada kelas diameter (CAI family at diameter class)

\begin{tabular}{ccccccccc}
\hline $\begin{array}{c}\text { Kelas } \\
\text { Diameter } \\
(\mathrm{cm}) \\
\begin{array}{c}\text { Diameter } \\
\text { class })\end{array}\end{array}$ & $\begin{array}{c}\text { Bursera- } \\
\text { ceae }\end{array}$ & $\begin{array}{c}\text { Diptero- } \\
\text { carpaceae }\end{array}$ & Fagaceae & Guttiferae & Lauraceae & $\begin{array}{c}\text { Myrta- } \\
\text { ceae }\end{array}$ & $\begin{array}{c}\text { Lain- } \\
\text { lain } \\
\text { (others } \\
\text { species })\end{array}$ & $\begin{array}{c}\text { Rata-rata } \\
\text { Average) }\end{array}$ \\
\hline $10-20$ & 0,91 & 1,66 & 1,72 & 1,43 & 1,79 & 1,54 & 1,32 & 1,48 \\
$20-30$ & 1,19 & 1,21 & 1,21 & 1,01 & 1,13 & 1,19 & 1,33 & 1,18 \\
$30-40$ & 1,19 & 1,07 & 1,14 & 0,93 & 0,87 & 1,22 & 1,28 & 1,10 \\
$40-50$ & 1,20 & 1,04 & 1,11 & 0,96 & & 0,87 & 1,11 & 1,05 \\
$50-60$ & 0,99 & & 1,00 & 0,65 & 0,98 & 0,85 & 0,89 \\
$60-70$ & 0,68 & 0,85 & & & 0,60 & 0,81 & 0,95 & 0,78 \\
70 up & 1,03 & 1,08 & 1,33 & 1,06 & 1,22 & 1,10 & 1,20 & 1,14 \\
\hline Rata-rata & 0,79 & & 0,42 & & 0,92 & 0,68 & 0,70 \\
\hline
\end{tabular}

Berdasakan Tabel 3. terlihat bahwa pada kelas diameter 10-20 cm di tahun kedua meningkat sebanyak $0,87 \mathrm{~cm}$ dari tahun pertama dan di tahun kelima meningkat sebanyak 2,14 cm dari tahun keempat. Rata-rata CAI pada kelas diameter $10-20 \mathrm{~cm}$ adalah $1,43 \mathrm{~cm} /$ tahun. Kecenderungan pe-ningkatan riap diameter ini dapat terjadi pada setiap kelas diameter, tetapi tidak sebesar kelas diameter 10-20 cm. Namun, bila riap diameter di-bandingkan berdasarkan klasifikasi komersil dan non-komersil maka riap diameter kelompok ko-mersil lebih tinggi dibanding non-komersil (Gam-bar 2).

Berdasarkan Gambar 2, dapat dilihat bahwa riap diameter jenis komersil lebih besar dari nonkomersil. Pada kelas diameter 50-60, riap diameter kelompok komersil mencapai $0,8 \mathrm{~cm} /$ tahun lebih besar dibanding kelompok jenis non-

Berdasarkan Tabel 4 di atas, kelas diameter 10-20 cm untuk famili Lauraceae memiliki riap lebih besar daripada famili lain, sementara pada kelas diameter $20-30 \mathrm{~cm}$, riap terbesar ada pada kelompok Dipterocarpaceae dan Fagaceae. Pada kelas diameter $30-40 \mathrm{~cm}$, riap diameter terbesar adalah famili Burceraceae. Rata-rata riap dia-meter terbesar berdasarkan famili adalah famili fagaceae. Sementara pada setiap kelas diameter untuk semua jenis menunjukkan bahwa riap diameter pada kelas diameter $10-20 \mathrm{~cm}$ sebesar $1,48 \mathrm{~cm} /$ tahun, kelas diameter 20-30 cm sebesar 1,18 cm/tahun dan kelas diameter $30-40 \mathrm{~cm}$ sebesar 1,10 $\mathrm{cm} /$ tahun dan kelas diameter $40 \mathrm{~cm}$ ke atas sebesar $0,86 \mathrm{~cm} /$ tahun. komersil yang hanya mencapai $0,6 \mathrm{~cm} /$ tahun Hasil penelitian ini mendukung Sumarna et al., (2002) dalam Purnomo et al., (2005) bahwa riap diameter rata-rata tahunan mencapai $0,59 \mathrm{~cm} /$ tahun untuk jenis komersil dan untuk jenis non komersil mencapai $0,53 \mathrm{~cm} /$ tahun. Hasil penelitian ini juga memperkuat pendapat Suhendang (2002) dalam Purnomo et al., (2005) bahwa asumsi riap dalam sistem TPTI sebesar $1 \mathrm{~cm} /$ tahun untuk jenis komersil tidak dapat diterima.

\section{Sebaran riap diameter berdasarkan famili}

Potensi pertumbuhan diameter setiap jenis berbeda. Distribusi diameter untuk hutan tidak seumur di suatu area tidak beraturan, tetapi kecenderungan pertumbuhan diameter dapat digambarkan dalam bentuk J terbalik (Husch et al., 2003). Namun tidak demikian dengan laju pertambahan diameter pohon yang dapat dilihat pada tabel 4 .

\section{Model pendugaan CAI setiap famili}

Setiap jenis memiliki karakteristik CAI diameter yang berbeda. Hal ini dipengaruhi oleh sifat toleran dan intoleran jenis tersebut, kebutuhan ruang tumbuh dan faktor kompetisi dan perbedaan oleh ukuran diameter. Adapun model terbaik penduga CAI disajikan pada Tabel 5 berikut.

Berdasarkan Tabel 5, pada semua kelompok jenis memiliki koefisien determinasi $\left(\mathrm{R}^{2}\right)$ sangat tinggi di atas $90 \%$. Hal ini menunjukkan bahwa model tersebut dapat menerangkan CAI diameter setiap famili dengan tepat. Informasi tentang model pendugaan CAI sangat berguna untuk memproyeksikan waktu pemanenan yang disesuaikan 
dengan siklus tebang. Adapun simulasi ukuran diameter setiap famili pada beberapa pilihan siklus tebang disajikan pada Gambar 4.

Berdasarkan Gambar 4 dapat dilihat bahwa famili Dipterocarpaceae dan Myrtaceae memiliki kecenderungan pertumbuhan diameter yang lebih besar dibandingkan famili yang lain. Pada diameter minimum $20 \mathrm{~cm}$ dengan siklus tebang 25 tahun, diameter kedua famili ini mencapai $48 \mathrm{~cm}$, sementara famili Guttiferae dan Fagaceae mencapai ukuran diameter 43 dan famili Lauraceae dan Burceraceae mencapai ukuran $37 \mathrm{~cm}$. Pada siklus tebang 30 dan 35 tahun, ukuran diameter famili Dipterocarpaceae dan Myrtaceae menca- pai 52 dan $56 \mathrm{~cm}$. Penetapan siklus tebang 25 tahun untuk 4 famili yakni Dipterocarpaceae, Fagaceae, Guttiferae dan Myrtaceae telah mampu mencapai batas minimal diameter tebang yakni di atas $40 \mathrm{~cm}$.

Hasil simulasi model ini mendekati hasil penelitian yang dilakukan oleh Wahyudi \& Pandjaitan (2011) bahwa diameter rata-rata jenis S. Leprosulla yang tergolong dalam famili Dipterocarpaceae pada umur 16 tahun mencapai 12,91$36,42 \mathrm{~cm}$ dengan MAI sebesar 1,36 cm/tahun. Perbandingan ini masih sangat kasar karena penelitian Wahyudi \& Pandjaitan (2011) dimulai dari semai sementara penelitian ini memproyek-

Tabel (Table) 5. Model penduga CAI setiap family (CAI Model at Each family groups)

\begin{tabular}{|c|c|c|c|c|}
\hline $\begin{array}{l}\text { Kelompok jenis } \\
\text { (Group of species) }\end{array}$ & $\begin{array}{l}\text { Jenis model } \\
\text { (Type of model) }\end{array}$ & $\begin{array}{c}\text { Model penduga } \\
\text { (Estimation model) }\end{array}$ & $\begin{array}{c}\text { Koefisien } \\
\text { (Determinasi) } \\
\left(\mathrm{R}^{2}\right) \\
\end{array}$ & $\begin{array}{c}\text { Simpangan Baku (s) } \\
\text { (Standard deviation, s) }\end{array}$ \\
\hline Burseraceae & Eksponensial & CAI $2,87 \mathrm{e}^{-0,049 \mathrm{D}}$ & $99 \%$ & 0,08 \\
\hline Dipterocarpaceae & Geometrik & CAI $0,578 \mathrm{D}^{\left(\frac{3,56}{\mathrm{D}}\right)}$ & $93 \%$ & 0,09 \\
\hline Fagaceae & Power & $\mathrm{CAI}=13.22 \mathrm{D}^{-0.796}$ & $97 \%$ & 0,108 \\
\hline Guttiferae & Geometrik & $\mathrm{CAI}=2 \mathrm{D}^{-0,0080}$ & $98 \%$ & 0,095 \\
\hline Lauraceae & Eksponensial & $\mathrm{CAI}=3,74 e^{-0,059 \mathrm{D}}$ & $99 \%$ & 0,098 \\
\hline Myrtaceae & Linear & $\mathrm{CA}=1,713-0,017 \mathrm{D}$ & $99 \%$ & 0,065 \\
\hline Keseluruhan & Eksponensial & $\mathrm{CAI}=2,19 e^{-0,0290}$ & $99 \%$ & 0,04 \\
\hline
\end{tabular}

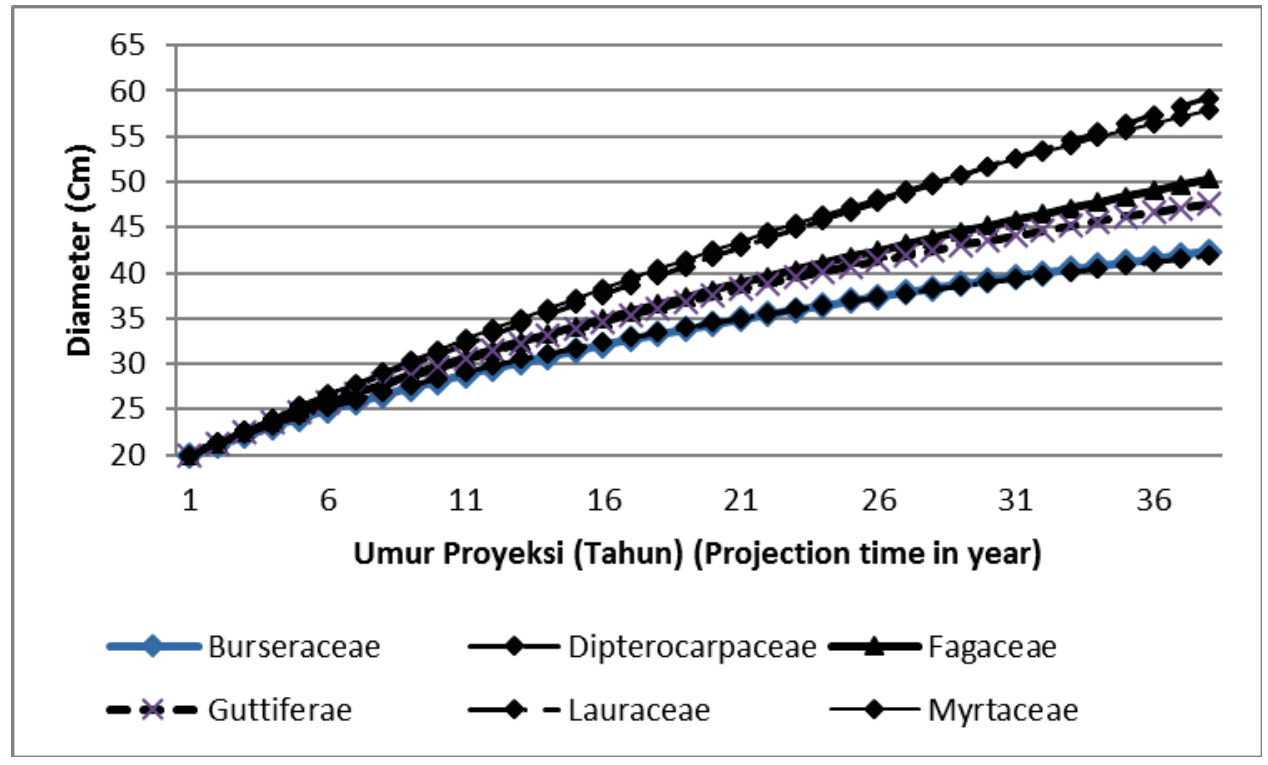

Gambar (Figure) 4. Simulasi pertambahan diameter berdasarkan pilihan siklus tebang (Diameters growth based on cutting cycle option) 
sikan pertumbuhan diameter minimal $20 \mathrm{~cm}$ pada awal daur. Hasil penelitian ini juga tidak berbeda dengan jenis Dipterocarpaceae lainnya yakni jenis Shorea johorensis. Menurut Lahjie (2013) bahwa pertumbuhan diameter S. Johorensis di umur 30 tahun mencapai $41,6 \mathrm{~cm}$, dan di tahun ke 35 mencapai $46,7 \mathrm{~cm}$. Sementara untuk diameter jenis D. lanceolata di umur ke-30 dan ke-35 mencapai $34,2 \mathrm{~cm}$ dan $39,0 \mathrm{~cm}$.

\section{B. Pembahasan}

Pendugaan pertumbuhan diameter berbasis jenis dan/atau kelompok jenis merupakan pendekatan yang lebih terurai pada pertumbuhan diameter suatu jenis dan untuk penentuan preskripsi pengelolaan hutan. Dalam penelitian ini dapat dilihat bahwa ciri pertumbuhan diameter ketika dipisahkan menurut kelompok jenis sangat berbeda. Hal ini sangat terkait dengan fisiologi pohon tersebut, kemampuan untuk tumbuh dalam bentuk hutan campuran dengan pola kompetisi terbuka. Selain itu, Pretzsch (2009) menjelaskan bahwa pertumbuhan merupakan fungsi dari kondisi lahan, struktur tegakan, sumber benih atau genotip. Kondisi lahan di sini terkait tipe topografi dan kelerengan serta keterbukaan lahan. Sementara faktor struktur tegakan terkait komposisi jenis yang ada di tegakan. Hal ini juga dibuktikan oleh Kariuki, Rolfe, Smith, Vanclay \& Kooyman (2006) bahwa pengaruh keruangan dan waktu dalam pertumbuhan pohon pada level tegakan adalah berbeda berdasarkan komposisi kelompok jenis dan gradien lingkungan. Respon pertumbuhan yang tinggi dapat ditemukan di bawah tajuk jenis-jenis intoleran terdapat jenis toleran yang tumbuh baik. Terkait variabel keruangan, Czaran (1998) dalam Berger, Piou, Schiffers dan Grimm (2008) terdapat 3 hal utama yang harus dipertimbangkan yakni modification, adaptation, dan belowground competition. Dengan pertimbangan 3 aspek ini maka Berger, Piou, Schiffers, \& Grimm (2008) mengembangkan menjadi 10 aspek yakni exploitation, heterogenity, modification, configuration, symetry, belowgroun competition, adaptation, avoidance dan interference.

Penelitian terkait proyeksi pertumbuhan melalui pembangunan model penduga dewasa ini tidak lagi mempertimbangkan aspek biofisik saja, melainkan juga melibatkan aspek-aspek lainnya. Debeljak, Poljanec \& Zenko (2014) menggunakan pendekatan "mining data" dalam memodelkan pertumbuhan tegakan hutan berbasis data inventarisasi. Pendekatan "mining data" ini salah satunya dengan melibatkan faktor indeks produktivitas lahan, elevasi dan kepemilikan lahan. Mereka menyimpulkan bahwa pertumbuhan hutan yang baik jika memiliki indeks produktivitas di atas 9 dan berada pada ketinggian $600 \mathrm{mdpl}$ untuk hutan milik atau di atas 700 mdpl untuk hutan negara dan berada pada daearh yang bukan berbatu.

Model penduga CAI diameter famili Dipterocarpaceae adalah berbentuk geometrik dengan $\mathrm{R}^{2}$ sebesar 99\% lebih baik dibandingkan model yang disusun oleh Saaludin, Yahya, Harun, \& Wan Ahmad (2014), yang menggunakan model regresi berganda untuk menduga pertambahan riap diameter jenis Dipterocarpaceae. Adapun model yang dihasilkan adalah sebagai berikut $L n$ $(D I+1)=0,236+55,898 B A+0,003 D B H-0,002$ $B A L$, dengan $\mathrm{R}^{2}$ sebesar $89,8 \%$.

Penyusunan model penduga riap berdasarkan jenis ini dapat dijadikan alat penduga potensi tegakan tinggal paska penebangan. Informasi ini sangat penting untuk menentukan tindakan silvikultur yang tepat serta menentukan daur tebangan. Akindele \& Onyekwelu (2011) menyebutkan bahwa komposisi jenis tegakan tinggal, kelimpahan permudaan alam dan kondisi biofisik, edafis dan klimatis sangat menentukan penentuan pilihan sistem silvikultur yang dapat diterapkan. Riap pertumbuhan diameter berdasarkan kelompok jenis sangat berbeda. Perbedaan sifat pertumbuhan diameter yang berbeda membuktikan bahwa penentuan batasan minimum diameter secara seragam dalam pengaturan hasil dapat ditinjau kembali. Merujuk pada Peraturan Menteri Kehutanan Nomor P.11/Menhut-II/2009 tentang Sistem Silvikultur dalam Areal Izin Pemanfaatan Hasil Hutan Kayu pada Hutan Produksi, batas diameter tebang adalah $40 \mathrm{~cm}$ ke atas maka semua jenis komersil pada ukuran diameter $40 \mathrm{~cm}$ up akan ditebang. Pada kondisi maka semua jenis yang tergolong komersil dan memiliki ukuran diameter di atas $40 \mathrm{~cm}$ akan ditebang habis, sementara jenis-jenis komersil yang tidak ditebang akan mengalami kerusakan tinggi. Selain itu, pertumbuhan jenis-jenis nonkomersil akan lebih tertekan karena ruang tumbuh yang semakin sempit.

\section{KESIMPULAN DAN SARAN}

\section{A. Kesimpulan}

Dari hasil penelitian dapat disimpulkan sebagai berikut: 
1. Riap setiap kelas diameter bervariasi antara $1,3 \mathrm{~cm} /$ tahun pada kelas diameter $10-20 \mathrm{~cm}$ sampai dengan 0,78 pada kelas diameter terbesar $60 \mathrm{~cm}$ ke atas.

2. CAI diameter kelompok jenis komersil lebih besar dibandingkan kelompok jenis nonkomersil. Pada kelas diameter 50-60, riap diameter kelompok komersil mencapai 0,8 $\mathrm{cm} /$ tahun lebih besar dibanding kelompok jenis non-komersil yang hanya mencapai 0,6 $\mathrm{cm} /$ tahun.

3. Model matematika CAI diameter kelompok jenis Dipterocarpaceae dan Guttiferae adalah bentuk geometrik. Model matematika CAI diameter pada kelompok jenis Burceraceae dan Lauraceae adalah eksponensial. Model matematika CAI diameter pada kelompok jenis Fagaceae adalah bentuk power dan kelompok jenis Myrtaceae adalah bentuk linier. Bentuk model matematika CAI diameter secara umum untuk semua jenis di hutan alam adalah bentuk eksponensial yakni $2,19 e^{-0,028 \mathrm{D}}$.

\section{B. Saran}

1. PUP merupakan sumber data terbaik yang harus dikelola dengan baik sehingga mampu memprediksi pertumbuhan hutan alam produksi.

2. Penentuan batas limit diameter tebang harus mempertimbangkan jenis prioritas pada suatu unit pemanfaatan hasil hutan kayu pada hutan alam produksi.

\section{DAFTAR PUSTAKA}

Agustini, K. (2006). Ingrowth dan upgrowth di hutan alam bekas tebangan untuk jenis komersial Tidak diterbitkan (Studi kasus di HPH PT. Suka Jaya Makmur, Kalimantan Barat). Skripsi. Departemen Manajemen Hutan Fakultas Kehutanan, Institut Pertanian Bogor.

Akindele, S.O., \& Onyekwelu, J.C. Onyekwelu. Review silviculture in secondary forest. Editors: Gunter, S. Weber, M., Stimm,B., \& Mosandl,R. (2011). Silviculture in The tropics. springer.

Berger, U., Piou, C., Schiffers, K., \& Grimm, V. (2008). Competition among plants: Concepts, individual-based modelling approaches, and a proposal for a future research strategy. Perspectives in Plant Ecology, Evolution and Systematics 9: 121-135.

Debeljak, M., Poljanec, A., \& Zenko, B. (2014).Modelling Forest graving stock from inventory data : data miring approace. Ecological Indicators: 30-39.
Gourlet-Fleury, S., Blanc, L., Picard, N., Sist., P., Nasi, R., Swaine, N.D., et al. (2005). Grouping species for predicting mixed tropical forest dynamics: Looking for a strategy. Ann. For. Sci. 62: 785-796.

Husch, B., Beers, T. W., \& Kershaw, J. A. (2003). Forest Mensuration. New Jersey: Jogn Wiley $\&$ Sons, Inc.

Kariuki, M., Rolfe, M., Smith, R., Vanclay, J. K., \& Kooyman, R.M. (2006). Diameter growth performances varies with species functional group and habitat characteristics in subtropical rain forest. Jour. Forest Eco-logy and Management. 225: 1-14.

Kementerian Kehutanan. (2009). Peraturan Menteri Kehutanan Nomor P.11/Menhut-II/2009 tentang Sistem Silvikultur dalam Areal Izin Usaha Pemanfaatan Hasil Hutan Kayu pada Hutan Produksi. Jakarta

Kementerian Kehutanan. (2011). Surat Edaran Direktur Jenderal Bina Usaha Kehutanan Nomor. 10/BUHA-VI/2011. Jakarta

Lahjie, A.M. (2013). Analisis pertumbuhan dan kelayakan finansial hutan tanaman Shorea johorensis dan Dryobalanops lanceolata dengan Restorasi Sistem Silvikultur Indonesia (RSSI) sebagai model pengelolaan hutan alam berkelanjutan di Provinsi Kalimantan Timur. Optimalisasi Peran Silvikultur untuk Menjawab Tantangan Kehutanan Masa Depan (hal. 33-39). Makassar: Fakultas Kehutanan UN-HAS.

Parthama, P. (2002). Pengaturan hasil hutan alam produksi. Makalah Diskusi Penentuan AAC Hutan Alam Produksi Bekas Tebangan. Editor: Redhahari \& Sumaryono. Jakarta: Badan Litbang Kementerian Kehutanan dan DFIDRFP.

Purnomo, H., Rusolono, T., Muhdin, Tiryana, T., \& Suhendang, E. (2005). Making sustainable work for complex forests: towards adaptive forest yield regulation. Proceedings of International Workshop on Promoting Permanent Sample Plots in Asia and Pasific Region (hal. 11-46). Bogor: CIFOR.

Pretzsch, H. (2009). Forest dynamics, growth and yield. Springer

Saaludin, N., Yahya, Y., Harun, S., \& Wan Ahmad, W. S. (2014). Modelling individual tree diameter increment for Dipterocarpaceae and NonDipterocarpaceae in tropical rainforest. Journal of Research in Agriculture and Animal Science: 1-8 
Septiana, A.R. (2000). Simulasi penentuan jatah produksi Tahunan (JPT) hutan bekas tebangan: Studi Kasus di PT. Inhutani II Sub Unit Malinau Kalimantan Timur. Skripsi. Jurusan Manajemen Hutan, Fakultas Kehutanan Institut Pertanian Bogor. Bogor.

Vanclay, J.K. (1994). Modelling forest growth and yield: application to mixed tropical forest. Copenhagen: CAB International.

Vanclay, J.K. (1996). Growth models for tropical forests: A Synthesis of models and methods. Southern ClassUniversity.

Vanclay, J.K. (2003). Growth modelling and yield prediciton fo sustainable forest management. The Malaysian Forester 66(1): 58-69.
Wahyudi \& Pandjaitan, S. (2011). Model pertumbuhan dan hasil tanaman Shorea leprosula pada sistem Tebang Pilih Tanam Jalur teknik SILIN. Jurnal Penelitian Dipterocarpa. Vol. 5 (2): 37-46.

Yudistira, I. (2004). Pengorganisasian data riap diameter jenis-Jenis famili Dipterocarpa-ceae di Indonesia. Skripsi.(Tidak diterbitkan) Jurusan Manajemen Hutan. Fakultas Kehutanan. Iinstitut Pertanian Bogor. Bogor. 